\title{
Synchronization Types and Levels of Information
}

\author{
Robert Farkash \\ Higher Education Technical School of Professional Studies, \\ Novi Sad, Serbia
}

robert.farkash@gmail.com

\begin{abstract}
Genetic evolution describes the development of living organisms, where genes are the elementary replicators. Genetic evolution results in increasingly complex forms, whose orderliness (informedness) becomes increasingly greater. This is how the human brain has come into being, starting a new evolution - the evolution of information, with memes as its elementary replicators. While examining memetics, this paper points to some facts that have been unknown so far concerning the definition of the process of heredity, according to which it can be concluded that the reproduction of information is created due to the information exchange between two human beings. This, however, goes against the principle of Occam's razor, as it describes the evolution of genes and memes as different processes; genes only pass on genotypes that have appeared as a result of earlier instances of reproduction, and not the phenotype that emerges and takes shape during a lifetime. In the case of memes, however, the assumption has been a Lamarckian reproduction mechanism with phenotype inheritance (for example, if the information I pass on is not identical to the information I previously received, then I do not transmit the information in the form that emerged in previous instances of reproduction). That is unified in terms of genetics and memetics in that, instead of situating the reproduction of memes in communication through media, it is positioned in every instance in which our brain thinks of the given information. This new definition gives us a chance to understand the relationship between the information and the message. The message refers to the information which appears in the medium during the process of communication, and which is created by the information replicators and the medium replicators (the medium is the message and not the information). Following the model of information replicators, i.e. the memes, we are introducing the concept of a med as the medium replicator. Meds are elementary replicators that create hybrid media by creating various complexes. In support of a model in which media are constructed by meds in a modularized form, I refer to the concept of a mash-up, which essentially signifies media that are established as hybrids of elementary web applications.
\end{abstract}

Keywords: Cognition and Perception.

\section{Introduction}

Material published as part of this publication, either on-line or in print, is copyrighted by the Informing Science Institute. Permission to make digital or paper copy of part or all of these works for personal or classroom use is granted without fee provided that the copies are not made or distributed for profit or commercial advantage AND that copies 1) bear this notice in full and 2) give the full citation on the first page. It is permissible to abstract these works so long as credit is given. To copy in all other cases or to republish or to post on a server or to redistribute to lists requires specific permission and payment of a fee. Contact Publisher@InformingScience.org to request redistribution permission.
Human perception is based on many options generated in various fields of sensitive areas. Brodmann areas enabled functions between sensitive information and correlated sensations in the human brain. The human brain presents a physical border in relationship with analytic and synthetic propositions.

I. Kant's "critical philosophy" and Brodmann areas provide scientific sup- 
port to the understanding of all "circumstances" of media genesis.

Genes are replicators for living organisms and memes are replicators for information, meds are elementary replicators for media. During communication, it is not the memes (information) but the meds (message) that are reproduced. The med of relevance is present in the medium of the future, which establishes semantic cross-referencing in the space of information.

Art in signing of informations to audio/visual perception means whole sensitive sensations / $\mathrm{Mr}$ Cage done it in music with accent on his vorname as a music scale: sound C_A_G_E, Laurie Anderson has performed symfonie on "ice" - one of her most-cited performances, Duets on Ice, which she conducted in New York and other cities around the world, involved her playing the violin along with a recording while wearing ice skates with the blades frozen into a block of ice; the performance ended only when the ice had melted away. Two early pieces, "New York Social Life" and "Time to Go," were included in the 1977 compilation New Music for Electronic and Recorded Media, along with works by Pauline Oliveros and others. Two other pieces were included on Airwaves a collection of audio pieces by artists.

Many of Anderson's earliest recordings remain unreleased, or were only issued in limited quantities, such as her first single, "It's Not the Bullet that Kills You (It's the Hole)". That song, along with "New York Social Life" and about a dozen others, were originally recorded for use in an art installation that consisted of a jukebox that played the different Anderson compositions, at the Holly Solomon Gallery in New York City. Among the musicians on these early recordings are Peter Gordon on saxophone, Scott Johnson on guitar, Ken Deifik on harmonica, and Joe Kos on drums. Photographs and descriptions of many of these early performances were included in Anderson's retrospective book, Stories from the Nerve Bible.

During the late 1970s, Anderson made a number of additional recordings that were released either privately or included on compilations of avant-garde music, most notably releases by the Giorno Poetry Systems label run by New York poet John Giorno, an early intimate of Andy Warhol Among the Giorno-released recordings was You're the Guy I Want to Share My Money With, a double-album shared with Giorno and William Burroughs (the original release had one LP side for each artist, with the fourth side triple-grooved, one for each, so you'd get a different one, depending on where you put the needle down). In 1978, Anderson performed at The Nova Convention, a major conference involving many counter-culture figures and rising avant-garde musical stars, including William S. Burroughs, Philip Glass, Frank Zappa, Timothy Leary, Malcolm Goldstein, John Cage, and Allen Ginsberg She also worked with comedian Andy Kaufman in the late 1970s.

Experimental music lovers in the UK may know Laurie Anderson best for her 1981 hit O Superman, the eerie minimalist piece which peaked at number two in the UK chart. The Laurie Anderson sound has evolved as she grasped new technologies, adapting instruments and software to suit her genre-defining artistic vision. In more recent times, she became Nasa's first ever artist-inresidence and was part of the team behind the music for the opening ceremony for the Olympic Games in Athens.

Speaking to the BBC's Colin Grant, Laurie reflected on a career ever-defined by the technology available to her. "Many years ago, in the 70 s and $80 \mathrm{~s}$, the equipment I used was studio equipment. It was delicate, and broke all the time, and was a bunch of boxes. I put those boxes on stages - noone else was doing that. They were just made for the studio."

Much of her early work was intended as part of theatrical performance or to accompany artistic installations. Her first single, It's Not the Bullet that Kills You (It's the Hole), was used for an installation at the Holly Solomon Gallery in New York in which Laurie's music played from a jukebox. 


\section{Hacking instruments}

Modern times have given Laurie room to lose those early constraints and bring her experimental sound to more places than ever before. "I swore I would love to travel with no boxes. What I've been doing in the last year is writing a lot of software to replace those boxes."

As well as creating software, Laurie hacks her hardware too. In the 1970s, she re-jigged a violin, replacing horsehair with magnetic tape which triggers audio samples when the bow touches the strings. Another invention involved adapting a wooden table so it plays music... through your arms.

Laurie created her own software to pursue her artistic vision, but her affection for adapting and improving technology has its limits. "Does it really affect how people make music? Yes! It does. Does it affect it in the most important way? Probably not. Although if you ask me that on a different day I would probably give you a different answer because frankly the fact that everyone makes records now is both dazzling and horrifying."

Equally horrifying, she insists, is our contentment with sub-standard music compression, particularly the mp3 file format. "First of all," she said. "Half the parts are missing. You would put two guitars, and the compression would erase the separation - so the guitars were gone. It's just unbearable to hear a record that I have spent forever working on."

Her latest work, Delusion, heads to the Brighton Festival next month as part of a worldwide tour and is described as a personal meditation on life, language, memory and identity.

Of course many composers have used some audio software today for performing and making sound-music generating sensitive in human cognitions: Philip Glass, Brian Eno...

Audio software as like Ableton Live 8, Reason, Fruity Loops, Sony Acid Pro, Reason etc can be provided possibilities which can be wav files or midi files convert through creative processing into mp3.

Based on above mentioned I feel free to introduce Mr. Dick Higgins' comments.

"Art is one of the ways that people communicate. It is difficult for me to imagine a serious person attacking any means of communication per se. Our real enemies are the ones who send us to die in pointless wars or to live lives which are reduced to drudgery, not the people who use other means of communication from those which we find most appropriate to the present situation. When these are attacked, a diversion has been established which only serves the interests of our real enemies.

However, due to the spread of mass literacy, to television and the transistor radio, our sensitivities have changed. The very complexity of this impact gives us a taste for simplicity, for an art which is based on the underlying images that an artist has always used to make his point. As with the cubists, we are asking for a new way of looking at things, but more totally, since we are more impatient and more anxious to go to the basic images. This explains the impact of Happenings, event pieces, mixed media films. We do not ask any more to speak magnificently of taking arms against a sea of troubles, we want to see it done. The art which most directly does this is the one which allows this immediacy, with a minimum of distractions.

Goodness only knows how the spread of psychedelic means, tastes, and insights will speed up this process. My own conjecture is that it will not change anything, only intensify a trend which is already there. 
For the last ten years or so, artists have changed their media to suit this situation, to the point where the media have broken down in their traditional forms, and have become merely patristic points of reference. The idea has arisen, as if by spontaneous combustion throughout the entire world, that these points are arbitrary and only useful as critical tools, in saying that such-and-such a work is basically musical, but also poetry. This is the intermedial approach, to emphasize the dialectic between the media. A composer is a dead man unless he composes for all the media and for his world.

Does it not stand to reason, therefore, that having discovered the intermedia (which was, perhaps, only possible through approaching them by formal, even abstract means), the central problem is now not only the new formal one of learning to use them, but the new and more social one of what to use them for? Having discovered tools with an immediate impact, for what are we going to use them? If we assume, unlike McLuhan and others who have shed some light on the problem up until now, that there are dangerous forces at work in our world, isn't it appropriate to ally ourselves against these, and to use what we really care about and love or hate as the new subject matter in our work? Could it be that the central problem of the next ten years or so, for all artists in all possible forms, is going to be less the still further discovery of new media and intermedia, but of the new discovery of ways to use what we care about both appropriately and explicitly? The old adage was never so true as now, that saying a thing is so don't make it so. Simply talking about Viet Nam or the crisis in our Labor movements is no guarantee against sterility. We must find the ways to say what has to be said in the light of our new means of communicating. For this we will need new rostrums, organizations, criteria, sources of information. There is a great deal for us to do, perhaps more than ever. But we must now take the first steps."

Dick Higgins

New York

August 3, 1966

\section{Wav or MIDI to MP3 in Context Human Cognition through Creative Process in Converting to Audio Software}

\section{Design/methodology/approach}

The printing of books brought about a break with the earlier continuity of the creationdevelopment of culture and the context of culture. In that way, the so-called one-sided/one-way Concept Culture was created on the basis of the "smashed" - disintegrated former sensitive and conceptual, visual and abstract units - codes. Concept culture was born as a result of dash - score character cascade. The context confirms the thesis of Kant's Critical Philosophy from $18^{\text {th }}$ century, which is in relation to the symbiosis of graphically expressive and reclusive dichotomy. Organic part of human brain is a medium of remembrance. Today's civilization follows the "save"-d learned knowledge and handled trouble maintaining and embalming the information.

Usually we ask how to save and transmit the accumulated knowledge. This can be manifested in a continuous conflict between homo-sapiens-human who is disposed to forget and populist contemporary society which has nominated institutions. The context of collected remembrance is a ground which is connecting many difference groups, from families as small cells to nations. The storing of the "save"-d and history of idea follow absolutely the "footnote"-s and reflections as some non-linear dialog. The works of Socrates' life we know are based on "false-untrue" (subjec- 
tive) documents from his lectures to his students. "Spoken words fly away, written words remain."

Wav files can be used in very creative methodology or in creation of midi files captures audio information. Some audio software provided possibilities to investigations in sound effects and creation new forms.

\section{Findings/Results}

Based on the above-mentioned we can conclude that during the development and explanation of various research areas, the learning material has been grooved up and thus made complex to be recognized. So, it is time to emphasize that demonstration instruments are getting more and more important and necessary for making of the learning material and we should seize the opportunity. Multimedia is presenting integrated possibilities for graphical implements-instruments. The audio-visual and sensual world of multimedia is presenting a real, crucial effect to acceptorsstudents/auditorium. Multimedia is a "gun" which can make miracles in the hands of competent experts while for somebody who starts into this field without a serious plan and concept it can be, unfortunately, more destructive than effective. The above-mentioned stuff is basically manifested through information-aggregate spreading. Interactive dichotomy as a discursive concept has absolutely participated in metonymy. Of course in education, there can be made two options within edu.methodology: the aspect of individual and the aspect of programming education.

Audio fields by video and text forms covering way in useful next software: Adobe After Effects, Sound Forge, Adobe Premier etc.

In practice implementations are means mixing of usefully software to fulfill in basically multimedia needs: text, sound and video.

Based on the "Summative Theory", some of the human receptors-replicators in relationship with "Brodmann areas" are in different relations-rates to the forming of knowledge in human environment within the mentioned learning environment: reading $10 \%$, hearing $20 \%$, eyesight $30 \%$, hearing\& eyesight $50 \%$, recital $70 \%$, act $90 \%$ as shown in Figure 1.

\section{Reflections Based on Summative Theory}

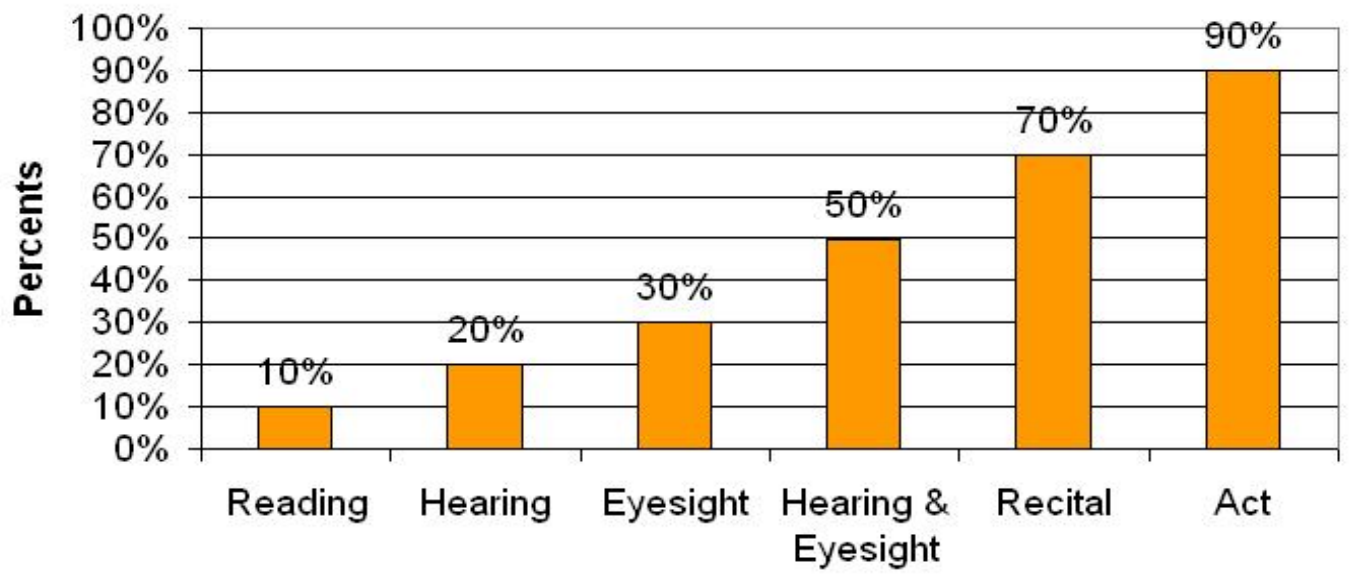

Relations

Figure 1: Reflections Based on Summative Theory 
All of the above-mentioned percentages confirm that multimedia has an effect on more receptors and thus increases the efficiency of learning. (See Figure 2.)

\section{The Control of Perception}

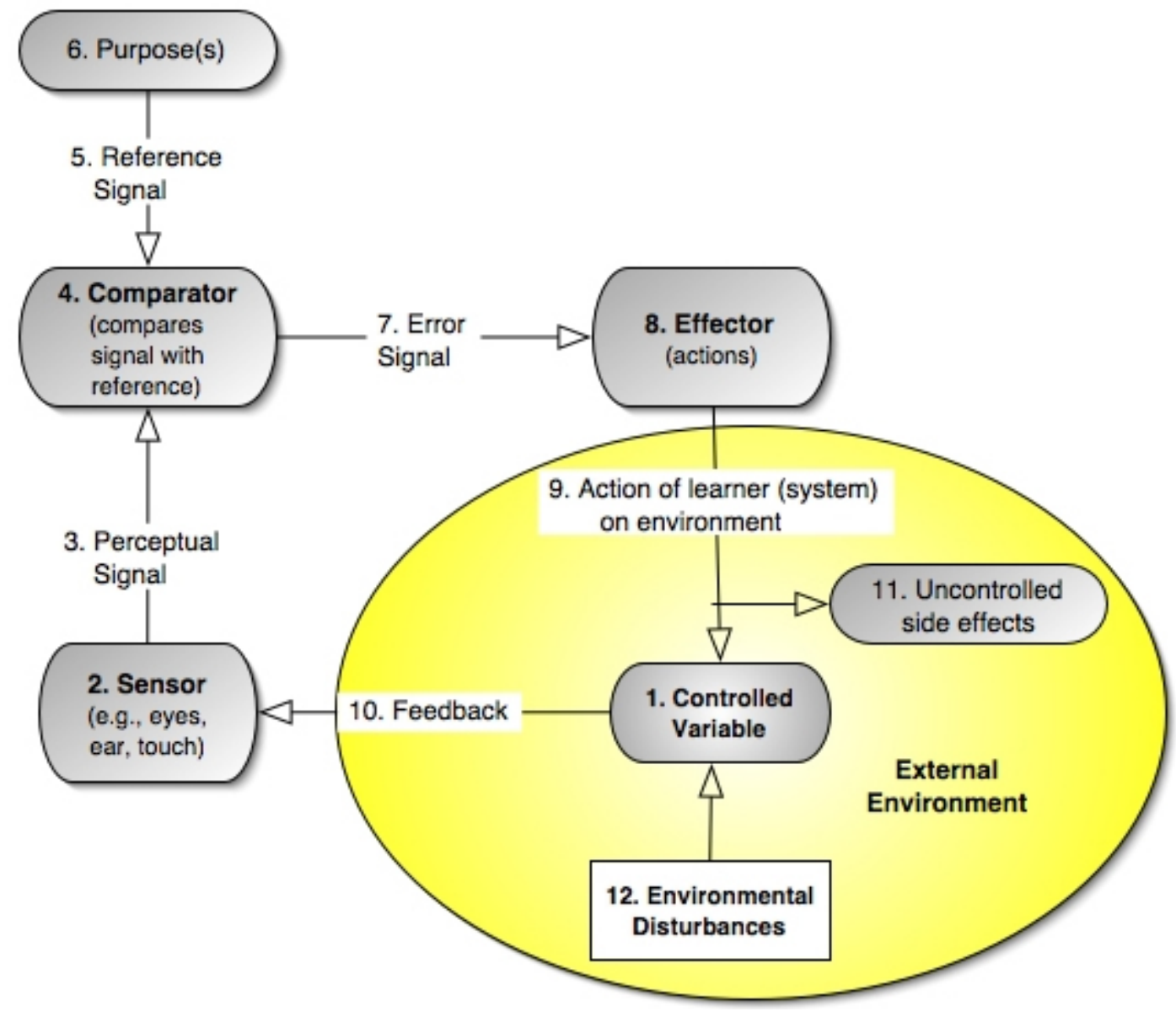

Figure 2. The Control of Perception 


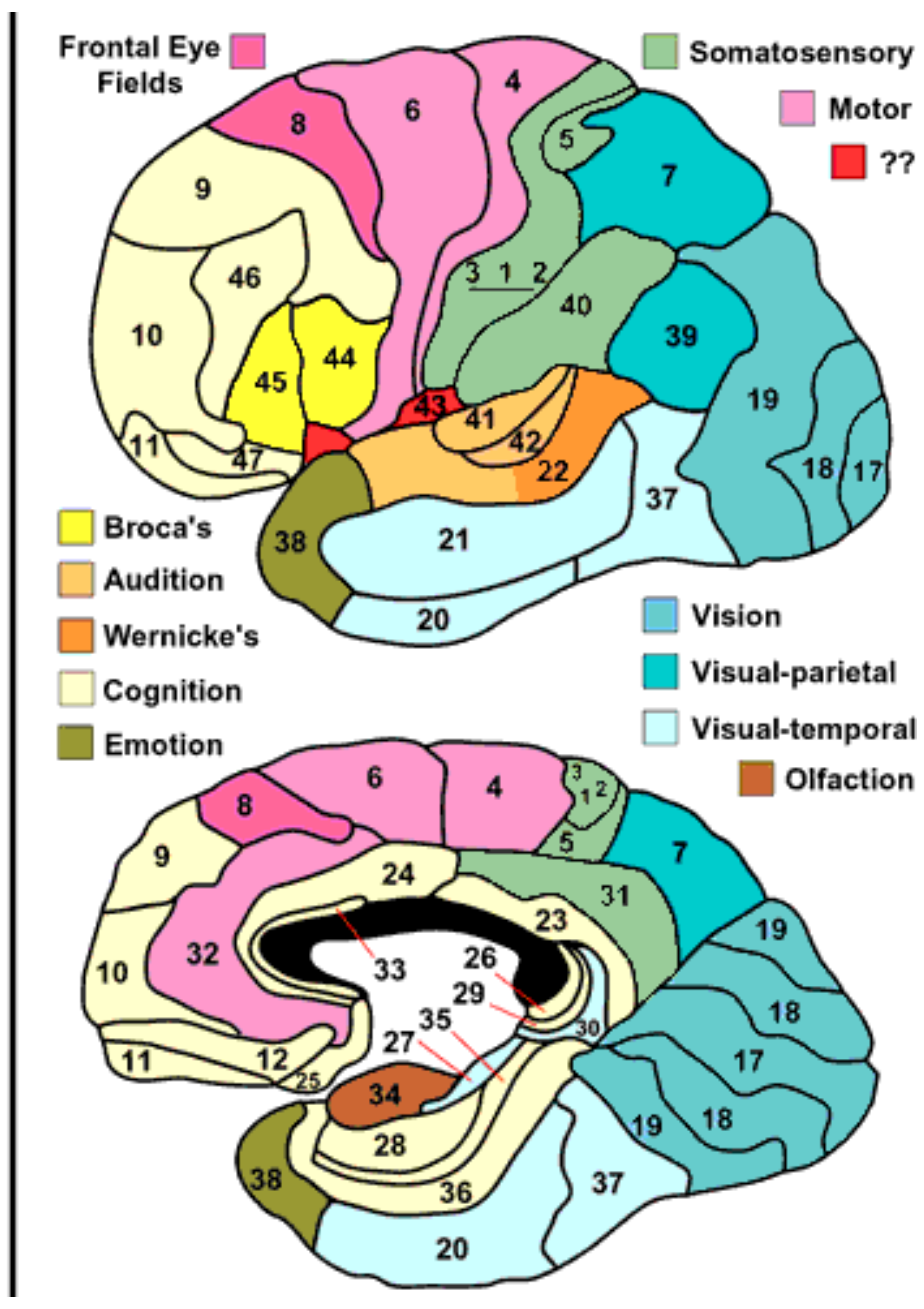

Figure 3. Brodmann areas

Brodmann areas were originally defined and numbered by the German neurologist Korbinian Brodmann based on the cortical cytoarchitectonic organisation of neurons he observed in the cerebral cortex using the Nissl stain (Figure 3). Brodmann published his maps of cortical areas in humans, monkeys, and other species in 1909, along with many other findings and observations regarding the general cell types and laminar organization of the mammalian cortex. (The same Brodmann area number in different species does not necessarily indicate homologous areas.)

A more detailed and verifiable cortical map have been published since then by Constantin von Economo and Georg N. Koskinas, which greatly improves the quality of the cytoarchitectonic classifications.

Brodmann areas have been discussed, debated, refined, and renamed exhaustively for nearly a century and remain the most widely known and frequently cited cytoarchitectural organization of the human cortex.

Many of the areas Brodmann defined based solely on their neuronal organization have since been correlated closely to diverse cortical functions. For example, Brodmann areas 1, 2 and 3 are the primary somatosensory cortex; area 4 is the primary motor cortex; area 17 is the primary visual cortex; and areas 41 and 42 correspond closely to primary auditory cortex. Higher order functions of the association cortical areas are also consistently localized to the same Brodmann areas by 
neurophysiological, functional imaging, and other methods (e.g., the consistent localization of Broca's speech and language area to the left Brodmann areas 44 and 45). However, functional imaging can only identify the approximate localization of brain activations in terms of Brodmann areas since their actual boundaries in any individual brain require its histological examination.

Kant created a new perspective on philosophy which had a widespread influence on philosophy continuing throughout to the 21 st century. He published important works on epistemology, as well as works relevant to religion, law, and history. One of his most prominent works is the Critique of Pure Reason.

Kant believed himself to be creating a compromise between the empiricists and the rationalists. The empiricists believed that knowledge is acquired through experience alone, but the rationalists maintained that such knowledge is open to Cartesian doubt and that reason alone provides us with knowledge. Kant argues, however, that using reason without applying it to experience will only lead to illusions, while experience will be purely subjective without first being subsumed under pure reason.

The two interconnected foundations of what Kant called his "critical philosophy" that created the "Copernican revolution" that he claimed to have wrought in philosophy were his epistemology of Transcendental Idealism and his moral philosophy of the autonomy of practical reason. These teachings placed the active, rational human subject at the centre of the cognitive and moral worlds.

\section{Theory of Perception}

\section{The Critique of Pure Reason}

Kant defines his theory of perception in his influential 1781 work The Critique of Pure Reason, which has often been cited as the most significant volume of metaphysics and epistemology in modern philosophy. Kant maintains that our understanding of the external world had its foundations not merely in experience, but in both experience and a priori concepts, thus offering a nonempiricist critique of rationalist philosophy, which is what he and others referred to as his "Copernican revolution".

Firstly, Kant's distinction between analytic and synthetic propositions:

1. Analytic proposition: a proposition whose predicate concept is contained in its subject concept; e.g., "All bachelors are unmarried," or, "All bodies take up space."

2. Synthetic proposition: a proposition whose predicate concept is not contained in its subject concept: e.g., "All bachelors are happy," or, "All bodies have weight."

\section{Practical Implications}

As media are complex systems, their structure emerges at cost of fragmentation. The irrevocable future outcome of complex systems is provided by a concept that originates from the natural sciences - that of entropy. This states that all closed systems inevitably succumb to disintegration and destruction. Order is always, and with certainty, moving towards future disorder. Unidirectional time, thus, points towards a state of maximum entropy. In all closed systems, operation and development require a continuous intake of external energy, which is gained from the environment.

Life on earth is also temporary; it has been made possible only as a result of the continuous energy supply provided by the sun. As they develop, systems decrease their entropy and increase their complexity, their informedness - in other words, their negentropy. What makes this possible is 
that their components act as replicators, which are in constant competition with their own variations before the shifting value system of the environment.

The autonomous development of complex systems is described by the concept of evolution. Evolutionary development and the movement towards maximum entropy are processes of opposite orientation; the future of the media will take shape between decay and development.

Genetic evolution describes the development of living organisms, where genes are the elementary replicators. Genetic evolution results in increasingly complex forms, whose orderliness (informedness) becomes increasingly greater. This is how the human brain has come into being, starting a new evolution - the evolution of information, with memes as its elementary replicators. While examining memetics, this paper points to some facts that have been unknown so far concerning the definition of the process of heredity, according to which it can be concluded that the reproduction of information is created due to the information exchange between two human beings. This, however, goes against the principle of Occam's razor, as it describes the evolution of genes and memes as different processes; genes only pass on genotypes that have appeared as a result of earlier instances of reproduction, and not the phenotype that emerges and takes shape during a lifetime. In the case of memes, however, the assumption has been a Lamarckian reproduction mechanism with phenotype inheritance (for example, if the information I pass on is not identical to the information I previously received, then I do not transmit the information in a form that emerged in the previous instances of reproduction). That is unified in terms of genetics and memetics in that, instead of situating the reproduction of memes in communication through media, it is positioned in every instance in which our brain thinks of the given information. This new definition gives us a chance to understand the relationship between the information and the message. The message refers to the information which appears in the medium during the process of communication, and which is created by the information replicators and the medium replicators (the medium is the message and not the information). Following the model of information replicators, i.e. the memes, we are introducing the concept of med as a medium replicator. Meds are elementary replicators that create hybrid media by creating various complexes. In support of a model in which media are constructed by meds in a modularized form, I refer to the concept of mash-up, which essentially signifies media that are established as hybrids of elementary web applications.

The examining of the future of media raises the question: won't the countless new hybrid media which, as a result of technological developments, emerge with never before seen intensity - collapse into a state of non-information due to the tendency towards entropy? Will the evolution of media be able to avoid the extremes of the sameness or differentness, which lead into entropic depths? Will we be met with mere media noise scattered into a pandemonium of orderlessness and chaos, or the other extreme: a homogenized media consonance which, as a result of some unifying erosion, is smoothed into conformity, losing its rich complexity? What will ensure sustainable development in the middle ground between these two extremes? The success of media is determined by the selection process congruent with the current human value system (including, for example, the Flow experience, which describes our feelings of joy in relation to a system). While we are pointed in the direction of differentness by thematic media (pull media), which ensure the accessibility of millions of subculture Long Tail contents, the search for special contents requires ever greater efforts on our part. In the direction of sameness, we find mass media (push media), which offer uniform, mainstream contents to the wide masses, but thus provided information is not customized for individual receiver. In the interest of a sustainable future, media will avoid sliding into either extreme and develop towards the equilibrium of an evolutionarily stable strategy (ESS). The medium of the future will have the capability to provide relevant, personspecific contents (the advantage of pull media) without an effort on part of the receiver (the ad- 
vantage of the push media). The above-mentioned defines the med, which connects semantically related contents via horizontal cross-referencing.

\section{Conclusions}

$>$ The reproduction of memes does not take place during the process of communication, when one person relays a message to another; memes are reconstructed in a mutated form every time we think of the message.

$>$ Just as in the case of genes, no Lamarckian arrows need to be drawn for memes either. In other words, in the case of memes too, it is the genotype that is inherited; the evolutionary process is identical for both genes and memes.

$>$ Just as genes are replicators for living organisms and memes are replicators for information, meds are elementary replicators for media.

$>$ During communication, it is not the memes (information) but the meds (message) that are reproduced.

$>$ The med of relevance is present in the medium of the future, which establishes semantic cross-referencing in the space of information.

\section{References}

Adorno, T. W. (1995). Ästhetische theorie, 13. kiad., Frankfurt am Main, Suhrkamp.

Bannet, E. T. (1989). Structuralism and the logic of dissent. Barthes, Derrida, Foucault, Lacan. London: Macmillan.

Barthes, R. (1971). Réponses. Tel Quel, 47, 89-107.

Barthes, R. (1972). The structuralist activity. In Critical essays. (R. Howard, Trans.). Evanston: Northwest University Press.

Beuys, J. (1987). Aktive neutralität. Die Überwindung von Kapitalismus und Kommunismus. Wangen, FIU Verlag.

Beuys, J. (1989). Im Gespräch mit Knut Fischer und Walter Smerling. Kunst Heute Nr. 1, Köln, Kiepenheuer \& Witsch,

Bodemann-Ritter, C., \& Beuys, J. (1988). Jeder Mensch ein Künstler. Gespräche auf der documenta 5. 2. kiad. Frankfurt, Berlin, Wien, Verlag Ullstein GmbH

Croix, A. de la (1987). Barthes. Pour une éthique des signes. Brüsszel: Prisme.

Culler, J. (1983). Roland Barthes. London: Fontana.

Dienst, R-G. (1970). Noch Kunst, Neuestes aus deutschen Ateliers. Düsseldorf: Droste Verlag.

Eagleton, T. (1991). Ideology. An introduction. London: Verso.

Easthope, A. (1991). Literary into cultural studies. London: Routledge.

Feyerabend, P. (1974). Review discussions. Popper's objective knowledge. Inquiry,475-507.

Filliou, R. (1970). Lehren und Lernen als Aufführungskünste. Köln, New York: Verlag Gebr. König.

Forbes, J., \& Kelly, M. (1995). French cultural studies. An introduction. Oxford: Oxford University Press.

György, P. (2004). Az utópia ígéretétöl a heterotópia bizonytalanságáig. Tér és Hely - az esztétikai tapasztalat lehetőségei a globalizáció korában. Beszélö,1.

Hawkes, T. (1977). Structuralism and semiotics. London: Methuen. 
Heizer, M., Oppenheim, D., \& Smithon, R. (1998). Avalanche interview. In J. Kastner \& B. Wallis (Eds.), Land and environmental art. London, New York: Phaidon.

Jenks, C. (1993). Culture. London: Routledge.

Kim, J., \& Sosa, E. (1995). A companion to metaphysics. Oxford: Blackwell.

Leak, A. (1994). Roland Barthes: Mythologies. London: Grant \& Cutler.

Lenz, C. (Ed.). (1987). Hans von Marées. München.

Lendvai, Á. (2010). Hybrid Média. Budapest: DLA Disszertáció, MKE.

Popper, K. (1972). Objective knowledge. An evolutionary approach. Oxford, Oxford University Press.

Prior, A. N. \& Fine, K. (1977). Worlds, times and selves. London: Duckworth.

Rigby, B. (1991). Popular culture in France: A study of cultural discourse. London: Routledge.

Ross, K. (1995). Fast Cars, Clean bodies. Decolonization and the reordering of French culture. London \& Cambridge, MA: The MIT Press.

Sugár, J. (2007). A gondolkodás médiuma. Budapest: MKE.

Thody, P. (1984). Roland Barthes: A conservative estimate. London: MacMillan.

\section{Biography}

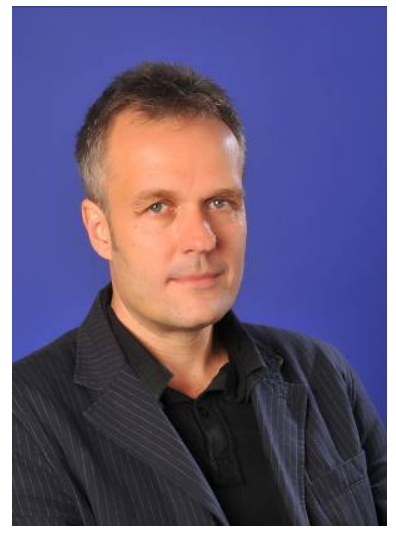

Phd Robert Farkas DLA is Doctor of Liberal Arts and Professor of Multimedia and Web Communications at the Higher Education Technical School of Professional Studies in Novi Sad, Serbia. He was born 1964, graduated at Academy of Art in Novi Sad 1991. MA finished 2009, DLA Doctor of Liberal Arts 2010 at Hungarian University of Arts Budapest,

http://www.mke.hu/dla/doktori fokozatszerzesek.php

http://robertfarkash.blogspot.com/ 